\title{
Identification and Assessment of Risk Factors Affecting Construction Projects in North Aceh, Indonesia
}

\author{
Anita Rauzana \\ Department of Civil Engineering, Syiah Kuala University, Jl. SyechAbdurRauf, Banda Aceh, Aceh Province, \\ Indonesia
}

\begin{abstract}
In the implementation of construction projects, contractors often face difficulties and events that obstruct the progress of work. Basically, it is an indicator of the lack of attention to the risks involved in the construction project. Lack of attention to the risks faced will affect the performance of the project which resulted in a loss to the parties involved in a construction project. The aims of this study was to identify risk factors that influence the construction project and determine the most dominant risk factors that effect on performance of the project. This research was conducted in construction projects in North Aceh. The data required in this research is the primary data in the form of the results of a questionnaire on risk factors and secondary data obtained from the literature data relating to research and data on the number of companies contracting. The risk factors that veryinfluence on the performance of the project in North Acehwas material factor.

Keywords: Management, risk, performance,constructionproject, contractors
\end{abstract}

\section{Introduction}

The construction project is unique and dynamic,in the implementation process is influenced by the productivity of labor, equipment, materials, budget and implementation methods. In the project work can be occurrence of uncertainty in its implementation will bring up a variety of risks that could ultimately affect the performance of the project itself. Because of the many contractors complain to the risks that often occur, which can result in losses that affecting the achievement ofthe desired goals. Risk is a condition where there is a possibility of profit / loss of economic or financial, physical harm or injury, delay, as a consequence of uncertaintyduring the implementation of the project.

The risk factors on the implementation of the project are an important thing to know. Therefore it is necessary to identify what risk factors that influence the performancein the construction project implementation. The aims of this study were to identify risk factors that influence the construction project and identifying the most dominant risk factor in the contracting in North Aceh.

Project risk is an uncertain event that, if it occurs, affects the achievement of the project's objectives positively or negatively (Hillson 2009; Williams 1995). Project risk is an inherent element in construction and contributes to a negative perception of the industry (Flyvbjerg et al. 2002). This perception is apparent in data collected from 557 members of the National Institute of Governmental Purchasing and the Institute of Supply Management. These individuals stated construction projects have more problems than any other goods and services purchased (Davison and Sebastian 2009b) and are the most likely to experience problematic consequences (Davison and Sebastian 2009a).

\subsection{Definition of Project Performance}

\section{Literature Review}

According toWibowo (2007), performance is the result of work and how the work progresses. Performance is the result of work that has a strong relationship with the organization's strategic objectives, customer satisfaction and contributes to the economy. Thus, the performance is a about how to do the work and results of the work. Project Performance is how does the project work by comparing the results of work in the field on estimate in the contract documents that have been agreed by the owner and the contractor. The performance indicators of cost, quality, time, and safety can measure project performance by planning carefully and thoroughly all over the allocation of human resources, equipment, materials, and costs in accordance with the necessary requirements.

\subsection{Risk Factors}

Kasidi (2010) states that the risk is the possibility of deviation from expectations that can result in losses. Risk is not enough simply avoided, but should be encountered withmethods to minimize the possibility of a loss. Types of Risk can be generally grouped into: 
1. Speculative Risk is the risk that it contains two possibilities, namely the possibility of beneficial or adverse possibilities. This risk is usually associated with business risk or business.

2. pureRisk is the risk that contains only one possibility, namely the possibility of losses. The risks faced by an organization or company is influenced by various factors both internal and external. External factors for examplerelated to the financial, government policies, market demand, and other regulations. Internal risks for example related to operations, processes, or worker. (Ramli, 2010)

The sources of risk can be classified into:

1. A social risk, the main source of this risk is the community. This means that actions of the people who create events that cause adverse deviation. For example: theft, riots, wars, etc.

2. The physical risk, there are many sources of physical risks, physical risk is a natural phenomenon and human behavior. For example: fire, weather, lightning, etc.

3. The economic risks, many risks faced by humans it is economic. For example: inflation, fluctuations. (Rauzana, 2015).

The risk should only be taken when the potential benefits and likelihood of success is greater than the costs required to cover possible failure. In connection with the project, the risk can be defined as the cumulative impact of occurrence of uncertainty that negatively impact on the project objectives (Soeharto, 2001).

\subsection{Definition of risk management}

According to Darmawi (2005), risk management is an attempt to find, analyze, and control the risks in every activity of the company in order to obtain effectiveness and efficiency of higher. The risk associated with uncertainty. According to Kasidi (2010), risk management is a business that is rationally shown to reduce possible losses.

\subsection{Identification and classification of risk}

According toKasidi (2010), Identification of risk is essentially an activity to accumulate all the information related to business activities. Then analyze them to find any risk that enables it can be a disadvantage. the implementation, risk identification can be performed by several techniques, among others:
1. Brainstorming
2. Questionnaire
3. Industry benchmarking
4. Scenario analysis
5. Risk assessment workshop
6. Incident investigation
7. Auditing
8. Inspection
9. Checklist
10. HAZOP (Hazard and Operability Studies)

According to Ramli (2010), Identification of risk is the foundation of accident prevention program or risk control. The risk factors that influence on the performance of the project based on previous research can be seen in Table 2.1.

Table 2.1. The risk factors that influence on the performance of the project

\begin{tabular}{|l|l|l|}
\hline & Risk Factors & Authors \\
\hline $\mathbf{X} \mathbf{1}$ & Material & \\
\hline 1 & Shortage of construction materials & Nadya(2014) \\
\hline 2 & Shortage of storage material & Honesti(2013) \\
\hline 3 & Delays in delivery of materials & Nadya(2014) \\
\hline 4 & Damage or loss (theft) material & Honesti(2013) \\
\hline 5 & Material scarcity & Nadya(2014) \\
\hline 6 & Inaccuracy time of booking materials & \\
\hline & & \\
\hline $\mathbf{X} 2$ & Equipment & Nadya(2014) \\
\hline 1 & Equipment damage & Nadya(2014) \\
\hline 2 & Equipment shortages & Nadya(2014) \\
\hline 3 & The productivity of tools & Honesti, (2013) \\
\hline 4 & Equipment incompatible with the working conditions & \\
\hline & & \\
\hline $\mathbf{X 3}$ & Financing & Nadya(2014) \\
\hline 1 & The availability of finance for implementation & \\
\hline
\end{tabular}




\begin{tabular}{|c|c|c|}
\hline 2 & Delay in payment processing by owner & Nadya(2014) \\
\hline 3 & $\begin{array}{l}\text { The lack of intensive money to the contractor } \\
\text { whencompletion time is faster than scheduled. }\end{array}$ & Nadya(2014) \\
\hline $\mathbf{X 4}$ & Environment & \\
\hline 1 & The effects of weather in the construction activity & Nadya(2014) \\
\hline 2 & The influence of the environmental safety on project & Nadya(2014) \\
\hline 3 & Geological issues at the site. & Nadya(2014) \\
\hline 4 & $\begin{array}{l}\text { The absence of communication between the contractors and } \\
\text { the community. }\end{array}$ & Nadya(2014) \\
\hline $\mathbf{X 5}$ & Economics & \\
\hline 1 & The inflation rate & Rauzana (2015) \\
\hline 2 & The interest rate & Rauzana (2015) \\
\hline 3 & Exchange rate & Rauzana (2015) \\
\hline 4 & Regional Minimum Wage & Rauzana (2015) \\
\hline 5 & Limitation the provision of credit & Rauzana (2015) \\
\hline $\mathbf{X 6}$ & Man Power & \\
\hline 1 & Shortage of labor. & Nadya(2014) \\
\hline 2 & Manpower capability & Nadya(2014) \\
\hline 3 & Competence of contractor. & Nadya(2014) \\
\hline 4 & Subcontractors or partners are not experts in the field. & Nadya(2014) \\
\hline 5 & Accidents and safety of workers & Honesti(2013) \\
\hline 6 & Understanding of the work specifications is not the same. & Nadya(2014) \\
\hline 7 & Interference or intervention of owner. & Nadya(2014) \\
\hline $\mathbf{X} 7$ & Planning & \\
\hline 1 & Permissions delays before implementation. & Nadya (2014) \\
\hline 2 & Design changes. & Nadya(2014) \\
\hline 3 & Design errors by planners. & Honesti(2013) \\
\hline 4 & Incomplete design & Honesti(2013) \\
\hline $\mathbf{X 8}$ & Management & \\
\hline 1 & Time control systems are weak. & Nadya(2014) \\
\hline 2 & Preparation of a sequence of events is not good. & Nadya(2014) \\
\hline 3 & Not conducted evaluation work specifications & Nadya(2014) \\
\hline 4 & The lack of operating procedures of each job. & Nadya(2014) \\
\hline 5 & Error in understanding about the contract documents & Nadya(2014) \\
\hline 6 & Occupational health and safety management is poor. & Nadya(2014) \\
\hline 7 & Internal conflicts in the project management team & Nadya(2014) \\
\hline 8 & Non-acceptance of work by owner & Honesti(2013) \\
\hline 9 & Quality management procedures are not appropriate. & $\operatorname{Nadya}(2014)$ \\
\hline $\mathbf{X 9}$ & Owner & \\
\hline 1 & Financial Failure owner & Subramanyan (2012) \\
\hline 2 & Change order & Rauzana (2016) \\
\hline
\end{tabular}

\subsection{Analysis of risk}

According to Ramli (2010), a risk analysis is intended to determine the extent of a risk concerning the possibility and consequence. Based on analysis of the risk rating that can be determined to do the sorting risks that have a major impact on the company and the risks are minor or ignored.

\subsection{Control of risks}

The risk is already known and potential consequences should be managed appropriately, effectively, and in accordance with the capacity and condition of the company. Risk management can be done with the variety of options, such as avoided, transferred to another party, or managed properly. (Ramli, 2010)

\subsection{Data Collection}

\section{Research Methodology}

Data used for research activities include primary data and secondary data. Primary data were data obtained through a questionnaire survey aimed to obtain relevant information for this study so getting valid and reliable data. In this study, using a questionnaire with the closed-format questions, the answer was already determined in advance and the respondent was not given an opportunity to answer the others. The questionnaire was designed in two parts, namely: 
1. Questionnaire in part A, include questions about the characteristics of the respondent and the identity of the company in general.

2. Questionnaire in part B, covering a number of questions about the risk factors that influence the performance of the project in North Aceh. In this section there are scales of measurement are categorized from "very lowinfluence" to "very highinfluence".

Secondary data were data obtained from the literature such as books and journals relating to research and the number of contractor companies from Construction Service Development Agency (LPJK). The target respondents are contracting parties in the North Aceh amounted to 47 companies. By using a sample obtained by Slovin formula:

$$
\begin{aligned}
n & =\frac{N}{1+N e^{2}} \\
& =\frac{53}{1+53(0,05)^{2}}=46,79 \sim 47
\end{aligned}
$$

\subsection{Validity Test}

According Arikunto (2010), the validity test is a measure that indicates the levels of validity or validity of an instrument. An instrument is said to be valid if it is able to measure what is desired. An instrument is said to be valid if it can reveal the data of the variables studied properly. High and low validity of the instrument indicates the extent of thethe data collected does not deviate from the description of the validity of the intended.

Pearson Product Moment:

$$
\mathrm{r}_{\mathrm{xy}}=\frac{n\left(\sum X Y\right)-\left(\sum X\right)\left(\sum Y\right)}{\sqrt{\left\{n \cdot \sum X^{2}-\left(\sum X^{2}\right)\right\}\left\{n \cdot \sum Y^{2}-\left(\sum Y^{2}\right)\right\}}}
$$

Where:

$\mathrm{X}=$ the score for each item of respondents trials the variable $\mathrm{X}$

$\mathrm{Y}=$ score for each item of respondents trials the variable $\mathrm{Y}$

$\mathrm{n}=$ number of respondents

\subsection{Reliability Test}

According to Arikunto (2010), reliability testing refers to an understanding that an instrument is trustworthy enough to be used as a means of data collection. Reliability test commonly used is the analysis of CAlpha coefficient. The test using Alpha Cornbach coefficient should be greater than or equal to 0.6 value is considered to be able to test the appropriateness of the questionnaire that was used. The formula used is as follows:

$$
\mathrm{r}=\frac{k}{(k-1)}\left[1-\frac{\sigma_{b}^{2}}{\sigma_{1}^{2}}\right]
$$

Where :

$\mathrm{r}=$ reliability of the instrument

$\mathrm{k}=$ number of items questions

$\sigma_{b}^{2}=$ Item variant

$\sigma_{1}^{2}=$ total of variance

The formulas for the variance and variance items total:

$$
\begin{aligned}
\sigma_{b}^{2} & =\frac{\sum x t^{2}}{n}-\frac{\left(\sum x t\right)^{2}}{n^{2}} \\
\sigma_{1}^{2} & =\frac{j k i}{n}-\frac{j k s}{n^{2}}
\end{aligned}
$$

Where:

$\sigma_{b}^{2}=$ total variance

$\sigma_{1}^{2}=$ variant of item

$\mathrm{Xt}^{2}=$ total number of respondents squares

$\mathrm{Xt}=$ total number of respondents

$J k i=$ sum of squared whole grains

$J k s=$ sum of squares subject

$n=$ number of respondents 


\subsection{Measurement Scale}

According to Sugiyono (2013), explains that the Likert scale is a scale used to measure attitudes, opinions, and perceptions of a person or group of people about events or social phenomena. To get answers to be made an instrument (questionnaire) associated by any statement or gesture of support expressed by a word or a particular indicator. For purposes of analysis, the answer can be given a score, for example:
1. Very low influence
$=1$
2. Low influence $\quad=2$
3. Medium influence $=3$
4. High influence $\quad=4$
5. Very high influence $\quad=5$

\subsection{Descriptive Analysis}

Sugiyono (2013), states that descriptiveanalysis is a statistic that is used to describe the data that has been collected. The presentation is in the form of tables, charts, or diagrams. Descriptive analysis can be data, mean, the number of data values, the minimum value and a maximum value. Mean formula is as follows:

$$
\begin{aligned}
& \quad \mathrm{X}=\frac{x i}{n} \\
& \text { Where : } \\
& \mathrm{X}=\text { mean } \text { of variable } \mathrm{X} \\
& \mathrm{xi}=\text { the sum of the elements in the variable } \mathrm{x} \\
& \mathrm{n}=\text { number of subjects }
\end{aligned}
$$

\section{Results And Discussion}

Based on the validity of the test that has been performed on all of the statements in the questionnaire are valid, so it can proceed with the reliability test. While the value of Cronbach Alpha had a value of 0.89 , indicating that the level of constancymeasurement is very reliable. Based on the calculation of the mean value of all the indicators, the mean value for each risk factor based on the opinions of respondents can be seen in Table 2.2

Table 2.2. Level of Influence of Risk Factors

\begin{tabular}{|l|l|l|}
\hline & Factors & Mean \\
\hline X1 & Material & 4,353 \\
\hline X2 & Equipment & 4,352 \\
\hline X3 & Financing & 4,249 \\
\hline X4 & Environment & 4,238 \\
\hline X5 & Economic & 4,234 \\
\hline X6 & Man Power & 4,231 \\
\hline X7 & Planning & 3,891 \\
\hline X8 & Management & 3,879 \\
\hline X9 & Owner & 3,861 \\
\hline
\end{tabular}

Based on Table 4.1, the results showed that the most influential risk factor in North Aceh was material factor had a mean value of 4.353 .

\section{Conclusions}

Based on the results of the research showed that the most influential risk factor in North Aceh was material factor had mean value of 4,353. Material resources in a project could reach $40 \%-60 \%$ of the project costs, therefore it is very necessary controls in the use of construction materials. Uncontrolled use of materials would make cost overruns. One of the factors that influence the smooth running of the implementation of a construction project is the flow of material during implementation. Delay in arrival of construction materials that cause stockout current material inventory will be used make work to be delayed. This can indirectly influence the total implementation time and cost of the project.

In construction projects, procurement of material is the most important part, because of resource material can absorb up to $40 \%-60 \%$ of the project costs (Ritz, 1994). Therefore the use of good management techniques and appropriate to purchase, store, distribute, and calculate the construction material to be veryimportant. Placement of material is one of the jobs that are important to the achievement of program implementation time the construction project, because it can affect the length of time of implementation of the work. In the planning of the project materials needs to be done predictions carefully about the needs of supplies 
in each period, so that purchases made are not excessive, the need to evaluate the excess material every weekend to avoid excess stock of material, and the needs to take into account the rate of inflation will influence the rise and fall of prices of materials, Better planning (reducing human error) would reduce unnecessary spending, so the cost contractors more optimal.

\section{References}

[1]. Arikunto, S. (2010). Research Procedure A Practice Approach. Rineka Cipta, Jakarta.

[2]. Arikunto, S. (2013). Research Management, Rineka Cipta, Jakarta.

[3]. Asmarantaka, N. S.(2007). Influential Of Risk Analysis Project Performance In Batiqa Palembang Hotel Development, Journal, Department of Civil Engineering University of Sriwijaya.

[4]. Darmawi, H. (2005). Risk Management. PT.Bumi Aksara, Jakarta.

[5]. Davison, B., and Sebastian, R. (2009a). "An analysis of the consequencesof contract administration problems for contract types." $J$. Manage.Res., 1(2), 1-32.

[6]. Davison, B., and Sebastian, R. (2009b). "The relationship between contractadministration problems and contract type." J. Pub. Procur., 9(2),262-282.

[7]. Flyvbjerg, B., Holm, M. S., and Buhl, S. (2002). "Underestimating costsin public works projects: Error or lie?” J. Am. Plann. Assoc., 68(3),279-295.

[8]. Honesti, L. S., \& Nazwar, D. (2012) Identification of Risk Factors Affecting Performance On Irrigation Project in Kerinci district, Journal of Civil Engineering Department of the Faculty of Civil Engineering and Planning Institute of Technology Padang.

[9]. Hillson, D. (2009). Managing of risk in projects, Gower, Farnham, U.K.

[10]. Kasidi. (2010) Risk Management, Ghalia Indonesia, Bogor.

[11]. Nazir, M. (2005). Research Methods, Ghalia Indonesia, Bogor.

[12]. Ramli, S. (2010). Risk Management in K3 OHS Risk Management, Dian Rakyat, Jakarta.

[13]. Riduwan. (2003). Scale of measurement, Alfabeta, Bandung.

[14]. Rauzana, A. (2015). The Influence of Uncertainty Variables on Cost Estimation Lesson Learned From Construction Industry in Indonesia. Australian Journal of Basic and Applied Sciences. 9(7): 380-385.

[15]. Rauzana, A. (2016). The effect of the risk factors on the performance of contractors in Banda Aceh, Indonesia, ARPN Journal of Engineering and Applied Sciences, 11(15), 9496 - 9502.

[16]. Ritz, G.J. (1994),Total Construction Project Management, McGraw-Hill Education, Singapore.

[17]. Sevilla, C. (1993).Introduction to Research Methods, Universitas Indonesia Press, Jakarta.

[18]. Soeharto, I. (2001). Project Management, Erlangga, Jakarta.

[19]. Soepono, B. (1997), Applied Statistics, PT.Rineka Cipta, Jakarta.

[20]. Sugiyono. (2013), Mixed Methods, Alfabeta, Bandung.

[21]. Wibowo. (2007). Performance Management, PT. Raja Grafindo Persada, Jakarta.

[22]. Williams, T. (1995). "The need for new paradigms for complex projects.”Int. J. Project Manage., 17(5), $269-273$. 